\title{
First Molecular Identification of Sunfish in North Bali Water
}

\author{
I Made Oka Riawan ${ }^{1 *}$, Gede Iwan Setiabudi ${ }^{1}$, Made Merdana ${ }^{2}$, I Putu Mangku Mariasa ${ }^{3}$, \\ Kadek Teguh Wirasastra ${ }^{4}$
}

\author{
The Faculty of Mathematic and Natural Science, Ganesha Education University ${ }^{1}$ \\ Faculty of Veterinary Medicine, Udayana University ${ }^{2}$ \\ True Scuba Dive Center ${ }^{3}$ \\ NMS Bali ${ }^{4}$ \\ Singaraja, Bali \\ *Corresponding author: okasmansa@gmail.com
}

\begin{abstract}
Stranded Sunfish was found in North Bali, and we collected some part that was used for molecular identification. Samples were amplified at the d-loop locus (control region) using the PCR (Polymerase Chain Reaction) method. Primers used in PCR were H16498 as primary front (forward) and L15812 as reverse primer. Similarity value of $95 \%$ after alignment with Mola ramsayi (accession number accession AY940824) on GenBank wa obtained, with the gaps of the nucleotide was 1\%. The stranded sunfish identified using partial sequence mtDNA was the same species as the species Mola ramsayi.
\end{abstract}

Keywords: stranded fish, Mola ramsayi, partial sequence.

\section{INTRODUCTION}

Molidae is the family with large number of species, primarily pelagic members of the Tetraodontiformes. Commonly known as ocean sunfish, and have a distinctive laterally compressed shape and "chopped off" appearance [1-3]. The median fins is primarily for swimming, they lack of ribs, caudal bones, pelvic fins, spines and have fewer vertebrae than any other fish [4]. Unlike most fish, sunfish has two distinct larva phases. A typical Tetraodon-like larval and another highly transformative stage resulting in the complete absorption of the tail [1].

Members of Molidae distributed in both temperate and tropical waters. These coasltal regions include the Central and Southern of California , Malaga of Spain, Cape Town of South Africa, Kamogawa of Japan, Hua Lien of Taiwan's, Camogli of Italy and Galapagos Islands of Ecuador's. In Indonesia, sunfish are found in southern coastal region of Bali, particularly in the area of Lembongan and Penida Islands, which those islands are belong to Bali region [5]. It has never been recorded to occur in Northern coastal region of Bali.. The species of sunfish found in coastal regions of Lembongan and Penida is Mola ramsayi, with density of 1 individual per $6.8 \mathrm{~km}$ [6]. In 2017 a sunfish was found stranded in the North Bali. Rescue process have been tried out repeatedly, but the fish was suffered and unbalance when swimming and were finally declared died on location. The fish was brought to the Biology Laboratory of Ganesha Education University for identification. The present study aimed to identify the species using molecular identification.

\section{RESEARCH METHOD}

\section{Sample Collection and preparation}

The samples were obtained from stranded fish found in northern coastal of Bali, Singaraja. Sample were transported to the laboratory and the morphometrics such as the weight and length were measured. Some muscle tissues were collected for molecular identification.

\section{Extraction method}

DNA extraction of samples was carried out using the $10 \%$ chelex method [7]. Sample of muscle tissue was cut with the size of $\pm 2 \mathrm{~mm}$, immersed in $10 \%$ chelek solution, vented for 20 seconds and centrifuged for 20 seconds. The sample was then heated on a heatblock at $95^{\circ} \mathrm{C}$ for 45 minutes, mixed in a vortex and centrifuged for another 20 seconds.

\section{Polymerase chain reaction}

Samples were amplified at the d-loop locus (control region) using the PCR (Polymerase Chain Reaction) 
method. Primers used in PCR are H16498 (5'CCTGAAGTAAGAACCAGATG-3') as primary front and L15812 (5'-CCTCCCTAAGACTCAAGGAAG-3') as reverse primer [8]. The following is the mixture of reagents used in the PCR process for each sample. Master Mix: ddH2O: 10 ul, Primary 1: 1.25 ul, Primary 2: 1.25 ul, Bioline Ready Mix: $12.5 \mathrm{ul}$, Extraction template/DNA product: 1 ul.

All reagents are inserted and mixed into the PCR tube and run on a thermalcycler machine with the following temperature optimization. Pre-denaturation: $94^{\circ} \mathrm{C} \quad 15$ seconds, next denaturation $94^{\circ} \mathrm{C} 30$ seconds, annealing $50^{\circ} \mathrm{C}$ 30 seconds, extension: $72^{\circ} \mathrm{C} 45$ seconds, and continued to post-extension $72^{\circ} \mathrm{C} 5$ minutes. The PCR process was carried out as many as 38 cycles.

\section{Electrophoresis}

One percent agarose gel was used for the electrophosesis. This gel is made from a mixture of $80 \mathrm{ml} \mathrm{SB}$ buffer (sodium \& boric acid) and $0.8 \mathrm{mg}$ agarose. Both ingredients are mixed in a glass beaker or erlenmeyer flask and heated until completely dissolved. Next, the liquid is poured into the mold, then cooled for \pm 45 minutes until the gel thickens. Samples were prepared by mixing $1 \mu 1$ loading dye in $3 \mu 1$

TABLE I

BLAST RESULT STRANDED OCEAN SUNFISH (Mola ramsayi) WITH Mola ramsayi ACCESSION NUMBER AY940824 (Bass et al., 2005)

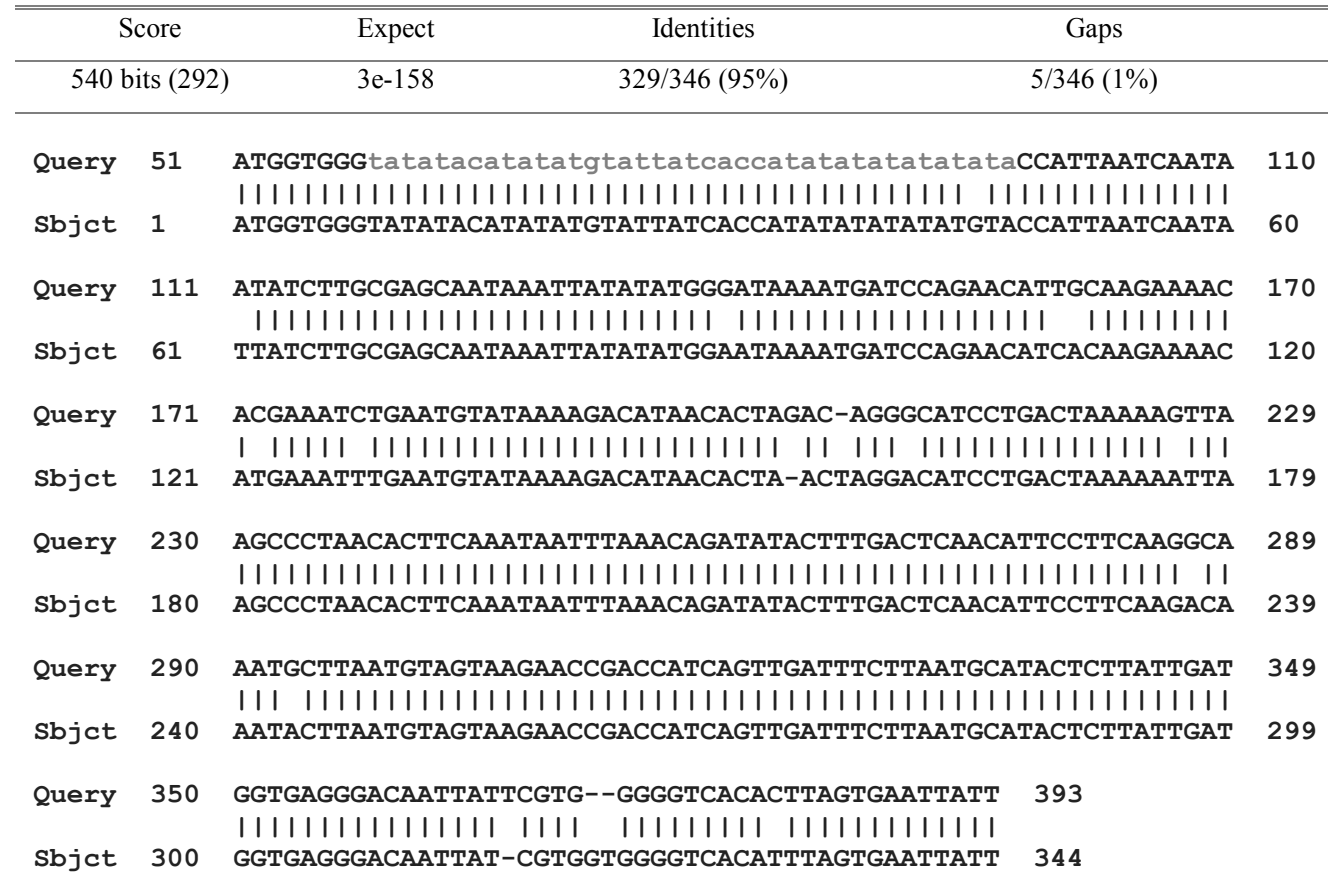

was still recorded of all sequence analyzed. This is probably due to the difference of the amplification primer used, namely H16498 (5'-CCTGAAGTAAGAACCAGATG-3 ') as primary front (forward) and L15812 (5'-
PCR product. Mixed samples were inserted in to the gel well. Lader marker was inserted on one end of the gel.

\section{Sequencing}

The amplified PCR product was sent for sequensing to the UC Berkeley sequencing facility following the method ofSanger. The sequences of DNA was analyzed in MEGA 6 and BLAST by comparing with Gene Bank to identify the fish species.

\section{RESULT AND DISCUSSION}

The total lengths of the partial loop mitochondrial amplification was 419 bp. The alignment of the mitochondrial DNA to the Bass et al. (2005) with the accession of AY940824found 95\% similarity with $1 \%$ nucleotide gaps (Table 1). Therefore, it was believe that using partial sequence mtDNA, the stranded sunfish found in Singaraja coastal region was similar to that of Mola ramsayi identified by Bass et al (2005) [3].

Mitochondrial DNA alignment in this study found that molecular characteristics of the stranded sunfish was very identical to the molecular data of the reference species from GenBank, that was Mola ramsayi. However, 5\% differences 
TATGCTTTAGTTAAGGCTACG-3') [3][9]. The primary difference allows the sequence variation amplified by the same in the same control loop region. To support the results of this alignment, morphology was also identified. The morphological characters refer to Fraser-Brunner [1].

Mola ramsayi and $M$. mola almost similar morphological character, described by Fraser-Brunner [1]. They share several unique anatomical features, of which the most striking is the lack of almost all osteological elements of the caudal fin structures, which are replaced by a pseudocaudal fin [4][10]. M. mola have rougher skin and reduced band of denticles running between their dorsal and anal fins along the pseudotail known as a clavus. In M. ramsayi, the clavus region is supported by 14-24 fin rays and 12 ossicle [5][11]. This character is in accordance with stranded sunfish in this study, after surgery to ensure ray structure found 16 fin rays in clavus and ends at the ossicle at the end of clavus. Whereas when on M. mola the clavus has 12 fin rays, eight of which bear ossicles [12]. Beside that, M. ramsayi does not have the smooth band at the base of the clavus [13-14], it similar to the specimen in this research. The stranded ocean sunfish were we found in this research has $173 \mathrm{~cm}$ total length, and $130 \mathrm{~cm}$ width (Table 2).

The phylogenetic tree (Figure 1) shown the relationship between species of Mola mola and Mola ramseyi, presented in three branches. The evolutionary history was inferred using the UPGMA method [15].

TABLE II

MORPHOMETRIC OF STRANDED OCEAN SUNFISH IN PRESENT STUDY (Mola ramsayi)

\begin{tabular}{llll}
\hline \hline \multicolumn{2}{c}{ Body Length $(\mathrm{cm})$} & \multicolumn{1}{c}{ Fins Length $(\mathrm{cm})$} \\
\hline Total length & 173 & Length of ventral fin & 78 \\
body width & 130 & Width of ventral fin & 30 \\
Length of clavus & 36 & Length of dorsal fin & 83 \\
Width of clavus & 82 & Width dorsal fin & 31 \\
\hline
\end{tabular}
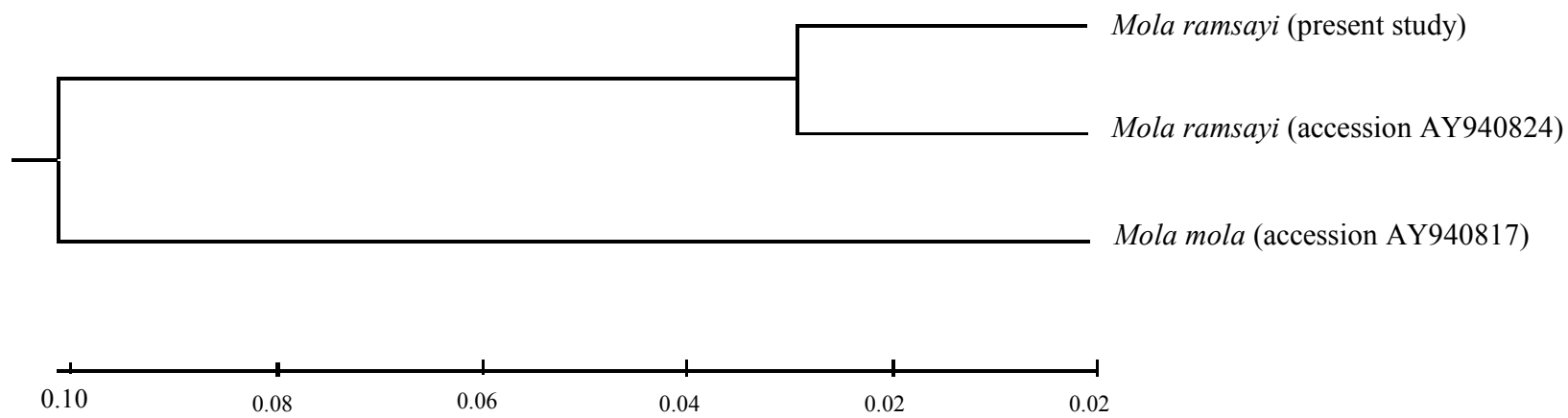

Fig. 1. Relationships of Mola ramsayi from present study and Mola from previous study by Bass et al., (2005)

The optimal tree with the sum of branch length= 0.23223534 was presented. The same lengh of tree units was used for the evolutionary distances. The evolutionary distances were calculted employing the Maximum Composite Likelihood method [16] and were in the units of the number of base substitutions per site. All positions containing gaps and missing data were eliminated. There were a total of 339 positions in the final dataset. Evolutionary analyses were conducted in MEGA6 [17]. It was found that the specific cluster of Mola ramsayi species has different molecular character to the Mola mola.

The morphological similarity between the specimens $M$. ramsayi (present study), and $M$. ramsayi were presented in Table 3. Both have similar morphological characters, those were by the present of smooth band, number of clavus fin rays, the ratios of ossicle size versus space between ossicle. [12]. The morphological characters of Mola seem to be well consistent with the key character of Mola ramsayi proposed by Fraser-Brunner [1], accept for the presence or absence of the smooth band. It may caused by age of the specimens, but further study is necessary [13][18].

In comparison Mola mola, the only other ocean sunfish species, they show similar dive behavior. Mola mola has been recorded in temperatures as low as $1.8^{\circ} \mathrm{C}$ off Japan [6][18] and high as $30^{\circ} \mathrm{C}$ off the southeast coast of the US and Bahamas [19-20]. The stranded M. ramsayi found in this study may have originated from the population of $M$. ramsayi in Lembongan Bali, the closest habitat of $M$. ramsayi found around Bali island. Research that has been carried out, $M$. ramsayi has random migration pattern They spent around 89 days for travelling in the distance of 747 $\mathrm{km}$. Migration of ocean sunfish was also found depended on abundance of prey, temperature and other factors [19][2122]. Further study is still required to investigated the cause of the stranded M. Ramsayi. Water pollution or other factor may contribute to this accorence. 
TABLE III

COMPARISON OF MORPHOLOGICAL CHARACTERS OF MOLA IN PRESENT STUDY SPECIMEN WITH OTHERS MOLA SPECIMEN FROM PREVIOUS STUDIES

\begin{tabular}{|c|c|c|c|c|c|}
\hline \multirow{2}{*}{ Species specimen } & \multirow{2}{*}{$\begin{array}{l}\text { Present study } \\
\text { M. ramsayi }\end{array}$} & \multicolumn{2}{|c|}{ Sawai et al., $2017 \mathrm{a}$} & \multirow{2}{*}{$\begin{array}{l}\text { Jawad, } 2012 \\
\text { M. ramsayi }\end{array}$} & \multirow{2}{*}{$\begin{array}{c}\text { Jawad et al., } 2013 \\
\text { M. mola }\end{array}$} \\
\hline & & M. ramsayi & M. mola & & \\
\hline Total length $(\mathrm{cm})$ & 173.0 & 91.6 & 91.6 & 135.0 & 135.0 \\
\hline Ossicles & 12 & $12-13$ & $11-13$ & 12 & 8 \\
\hline Clavus fin rays & 14 & 19 & No data & 16 & 12 \\
\hline Smooth band & Present & Present & Present & absent & Present \\
\hline $\begin{array}{l}\text { Ossicle size (OS) versus } \\
\text { width of spaces between } \\
\text { ossicles (SS) }\end{array}$ & $\mathrm{OS}>\mathrm{SS}$ & $\mathrm{OS}>\mathrm{SS}$ & $\mathrm{OS}>\mathrm{SS}$ & $\mathrm{OS}>\mathrm{SS}$ & $\mathrm{OS}<\mathrm{SS}$ \\
\hline Head bump & Absent & Absent & Absent & No data & No data \\
\hline Shape of clavus & Round & Round & Round & No data & No data \\
\hline
\end{tabular}

\section{CONCLUSION}

The sunfih which stranded on Singaraja coast was identified as Mola ramsayi which has been proven by $95 \%$ similarity from molecular identification of d-loop control region, partial sequence of mtDNA and morphological characters that correspond to the key characters of $M$. ramsayi.

\section{ACKNOWLEDGMENT}

This work was supported by NMS Bali for collecting tissue sample and preserving the sunfish. Bionesia Foundation who help to get partial sequence, and the Ministry of Marine Affairs and Fisheries who support this project.

\section{REFERENCES}

[1]Fraser-Brunner, A. 1951. The ocean sunfishes (family Molidae). Bulletin of the British Museum (Natural History), Zoology. 1: 87121.

[2]Smith, M.M, P.C. Heemstra. 1986. Smith's Sea Fishes, 6th edn. Springer, Berlin Heidelberg, New York.

[3]Bass, A.L, H. Dewar, T. Thys, J.T. Streelman, S. A. Kar 2005. Evolutionary divergence among lineages of the ocean sunfish family, Molidae (Tetraodontiformes). Marine Biology, 148(2): 405-414.

[4]Tyler, J.C. 1970. The progressive reduction in number of elements supporting the caudal fin of fishes of the order Plectognathi. Proc Acad Nat Sci Phila. 122. 1-85.

[5]Thys, T., M.J. Whitney, A. Hearn, K.C. Weng, C. Peñaherrera, L. Jawad, J. Alfaro-Shigueto, J.C. Mangel, A.K. Stephen. 2013. First record of the southern ocean sunfish, Mola ramsayi, in the Galapagos Marine Reserve. Marine Biodiversity Records. 6:1-4.

[6]Thys, T., J.P. Ryan, K.C. Weng, M. Erdmann, J. Tresnati. 2016. Tracking a marine ecotourism star: movements of the short ocean sunfish Mola ramsayi in Nusa Penida, Bali, Indonesia. Journal of Marine Biology, (2016): 6 pages.

[7]Walsh, P., D.A. Metzger, R. Higuchi. 1991. Chelex-100 as a medium for simple extraction of DNA for PCR based typing from forensic material. Biotechniques, 10: 506-513.

[8]Rosel, P.E., A.E. Dizon, J.E. Heyning. 1994. Genetic analysis of sympatric morphotypes of common dolphins (genus Delphinus). Marine Biology, 119(2): 159-167.

[9]Lee, WJ., J. Conroy, W.H. Howell, T.D. Kocher. 1995. Structure and evolution of teleost mitochondrial control regions. $J$ Mol Evol. 41:54-66.
[10] Sawai, E., Y. Yamanoue, L.A. Jawad, J. Al-Mamry, Y. Sakai. 2017a. Molecular and Morphological Identification of Mola Sunfish Specimens (Actinopterygii: Tetraodontiformes: Molidae) from the Indian Ocean. Species Diversity. 22:99-104.

[11] Sawai, E., Y. Yamanoue, M. Nyegaard, Y. Sakai. 2017b. Redescription of the bump-head sunfish Mola alexandrine (Ranzani 1839), senior synonym of Mola ramsayi (Giglioli 1883), with designation of a neotype for Mola mola (Linnaeus 1758) (Tetraodontiformes: Molidae). Ichthyological Research, 65: 142160 .

[12] Jawad, L., J. Al-Mamry, L. Al-Kharusi. 2012. Fist record of Mola ramsayi from the Sea of Oman, Sultanate of Oman. Marine Bidodiversity Record, 5: e63.

[13] Jawad, L. 2013. First documented record of the ocean sunfish, Mola ramsayi (Linnaeus) from the Sea of Oman, Sultanate of Oman (Teleostai: Molidae). Stuttgarter Beitrage zur Naturkunde, A (6): 287-290.

[14] Yoshita, Y., Y. Yamanoue, K. Sagara, M. Nishibori, H. Kuniyoshi, T. Umino, Y. Sakai, H. Hashimoto, K. Gushima. 2009. Phylogenetic relationship of two Mola sunfishes (Tetraodontiformes: Molidae) occurring around the coast of Japan, with notes on their geographical distribution and morphological characteristics. Ichthyological Research, 56: 232-244.

[15] Sneath, P.H.A., R.R. Sokal. 1973. Numerical Taxonomy. Freeman, San Francisco.

[16] Tamura, K., MM. Nei, S. Kumar. 2004. Prospects for inferring very large phylogenies by using the neighbor-joining method. Proceedings of the National Academy of Sciences (USA). 101: 11030-11035.

[17] Tamura K., G. Stecher, D Peterson, A. Filipski, S. Kumar. 2013. MEGA6: Molecular Evolutionary Genetics Analysis version 6.0. Molecular Biology and Evolution. 30: 2725-2729.

[18] Dewar, H., T. Thys, S.L. Teo. 2010. Satellite tracking the world's largest jelly predator, the ocean sunfish, Mola mola, in the Western Pasific. Journal of Experimental Marine Biology and Ecology, 393(1-2): 32-42.

[19] Potter, I.F., W.H. Howell. 2011. Vertical movements and behavior of the ocean sunfish, Mola mola in the Northwest Atlantic. Marine Biology. 158(3):531-540.

[20] Houghton, J.D.R., T.K. Doyle, J. Davenport, G.C. Hays. 2006. The ocean sunfish Mola mola: insights into distribution, abundance and behavior in the Irish and Celtic Seas. J. Mar. Biol. 86(5): 1237-1243.

[21] Thys, T.M., J.P. Ryan, H. Dewar, C.R. Perle, K. Lyons, J. O’Sullivan, C. Farwell, M.J. Howard, K.C. Weng, B.E. Lavaniegos, G.G. Castro, L.E.M Bojorquez, E.L. Hazen, S.J. Bograd. 2015. Ecology of the Ocean Sunfish, Mola mola, in the southern California 
Current System. Journal of Experimental Marine Biology and Ecology. 471:64-76.

[22] Santini, F., J.C. Tyler. 2003. A phylogeny of the families of fossil and extant teraodontiform fishes (Acanthomorpha, Tetraodontiformes), Upper Cretaceus to Recent. Zoological Journal of the Linnean Society. 139:565-617. 